\title{
PENGEMBANGAN SISTEM ADAPTIVE LEARNING MENGGUNAKAN METODE SAW(SIMPLE ADDITIVE WEIGHTING) UNTUK MENENTUKAN NILAI PEMBELAJARAN PADA MATA KULIAH METODE NUMERIK
}

\author{
I Made Gunarta Putra ${ }^{1}$, I Made Agus Wirawan ${ }^{2}$, Nyoman Sugihartini ${ }^{3}$ \\ 1,2,3 Jurusan Pendidikan Teknik Informatika/Universitas Pendidikan Ganesha \\ Singaraja ,Bali
}

e-mail: rojesancut@gmail.com ${ }^{1}$, imade.aguswirawan@undiksha.ac.id ${ }^{2}$, sugihartini@undiksha.ac.id ${ }^{2}$

\begin{abstract}
Abstrak
Penelitian ini bertujuan :(1) Untuk Pengembangan Sistem Adaptive Learning Menggunakan Metode SAW(Simple Additive Weighting) untuk Menentukan Nilai Pembelajaran pada Mata Kuliah Metode Numerik. (2) Untuk mengetahui hasil uji kesesuaian terhadap penggunaan Sistem Adaptive Learning Menggunakan Metode SAW(Simple Additive Weighting) untuk Menentukan Nilai Pembelajaran pada Mata Kuliah Metode Numerik dan (3) Untuk mengetahui dan mendeskripsikan respon mahasiswa Jurusan Pendidikan Teknik Informatika, Fakultas Teknik dan Kejuruan Universitas Pendidikan Ganesha terhadap penggunaan Sistem Adaptive Learning Menggunakan Metode SAW(Simpele Additive Weighting) untuk Menentukan Nilai Pembelajaran pada Mata Kuliah Metode Numerik. Jenis penelitian ini adalah penelitian dan pengembangan model ADDIE. Untuk proses pengujian dilakukan (5) tahap: (1) ujji whitebox, (2) uji blackbox, (3) uji ahli media, (4) uji kesesuaian, dan (5) uji respon pengguna. Hasil uji kesesuain menyatakan sudah sesuai dilihat dari perhitungan manual dengan hasil perhitungan system dan hasil uji respon pengguna menyatakan system berjalan baik dari rata-rata total respons pengguna sebesar $81,87 \%$.
\end{abstract}

Kata kunci: SPK, SAW, Adaptive Learning

\begin{abstract}
This study aims: (1) For Development of Adaptive Learning System Using SAW (Simple Additive Weighting) Method to Determine Learning Value in Numeric Method Subject. (2) To find out the result of conformity test to use of Adaptive Learning System Using Simple Additive Weighting Method to Determine Learning Value in Numeric Method Course and (3) To know and describe student response of Informatics Engineering Department, Faculty of Engineering and Vocational Ganesha University of Education on the use of Adaptive Learning System Using SAW (Simple Additive Weighting) Method to Determine the Value of Learning in the Numerical Method Subject. This type of research is the research and development with ADDIE model. The test process is performed (5) stage: (1) white box test, (2) black box test, (3) media expert test, (4) conformity test, and (5) user response test. The result of conformity test stated that it is appropriate to be seen from the manual calculation with the result of the calculation of the system and the result of user response test stated the system is running well from the average total user response of $81.87 \%$.
\end{abstract}

Keywords : SPK, SAW, Adaptive Learning

\section{PENDAHULUAN}

Belajar adalah suatu proses yang kompleks yang terjadi pada diri setiap orang sepanjang hidupnya. Proses belajar terjadi karena adanya interaksi antara seseorang dengan lingkungannya. Salah satu bertanda seseorang telah belajar 
adalah adanya perubahan pada tingkat pengetahuan, ketrampilan, atau sikap.

Proses pembelajaran dilaksanakan secara formal, dimaksudkan untuk mengarahkan perubahan pada diri peserta didik secara terencana, baik dalam aspek pengetahuan, ketrampilan, maupun sikap [1].

Seiring perkembangan teknologi informasi dan komunikasi yang semakin pesat memungkinkan pembelajaran tidak hanya dilakukan di dalam kelas namun bisa dilakukan di luar kelas, di mana saja dan kapan saja. Proses pembelajaran sangat di pengaruhi oleh perkembangan teknologi, teknologi sekarang ini sudah dapat digunakan untuk pembelajaran adaptif [2].

Mata kuliah Metode Numerik merupakan salah satu mata kuliah yang ada di jurusan Pendidikan Teknik Informatika. Materi dari Metode Numerik lebih banyak menjelaskan materi konsep yang bersifat hafalan sehingga untuk memahami materi tersebut membutuhkan waktu yang cukup banyak, tentunya di dalam penyampaian materi tersebut tidaklah cukup hanya di dalam kelas saja. Adapun kendala-kendala yang dihadapi dalam wawancara dengan Luh Putu Eka Damayanthi S.Pd., M.Pd selaku dosen pengajar mata kuliah Metode Numerik di jurusan Pendidikan Teknik Informatika Undiksha Singaraja pada hari/tanggal Selasa, 7 Juni 2016 :

a. Proses pembelajaran yang diberikan masih bersifat satu arah (teacher center learning) sehingga mahasiswa akan merasa bosan dalam menerima materi yang di sampaikan oleh dosen

b. Masih ditemukannya penilaian secara subjektif.

Selain permasalahan dari observasi dengan Putu Eka Damayanthi S.Pd., M.Pd adapun ditemukan kendala yang lain, di mana dari hasil penyebaran angket yang sudah dilakukan dengan responden mahasiswa yang mengambil mata kuliah Metode Numerik di dapatkan hasil minat belajar mahasiswa terhadap mata kuliah Metode Numerik masih dalam kategori sedang dan beberapa mahasiswa masih ada dalam kategori kurang.

Setiap peserta didik memiliki kemampuan kognitif yang berbeda-beda sehingga kemampuan pemahaman orang terhadap sesuatu hal juga berbeda, kemampuan kognitif dan keterampilan berpikir kritis merupakan hal esensial yang penting untuk dikembangkan dalam proses pembelajaran [3]. Maka untuk memaksimalkan pemahaman pebelajar terhadap materi Metode Numerik perlu dilakukan pembelajaran yang bersifat adaptif dan untuk mengukur pemahaman pebelajar terhadap materi yang disajikan perlu diadakannya evaluasi. Pemberian nilai dari hasil evaluasi pembelajaran adaptif dapat ditangani dengan Simple Additive Weighting (SAW) [2]. Metode SAW tepat digunakan pada penelitian ini, karena membantu untuk pemberian nilai pada tes adaptif. Metode SAW dapat menyelesaikan masalah yang sifatnya multiobjective termasuk kriteria kuantitatif dan metode ini dapat melakukan penilaian secara lebih tepat di mana didasarkan pada nilai kriteria dan bobot preferensi yang sudah ditentukan [4].

Berdasarkan permasalahan di atas, peneliti memandang perlu untuk di kembangkannya adaptive learning untuk mendukung proses pembelajaran pada mata kuliah Metode Numerik. Penelitian ini merupakan penelitian Pengembangan Sistem Adaptive Learning Menggunakan Metode SAW(Simple Additive Weighting) untuk Menentukan Nilai Pembelajaran pada Mata Kuliah Metode Numerik.

\section{KAJIAN TEORI}

A. Adaptive Elearning System (AES) 


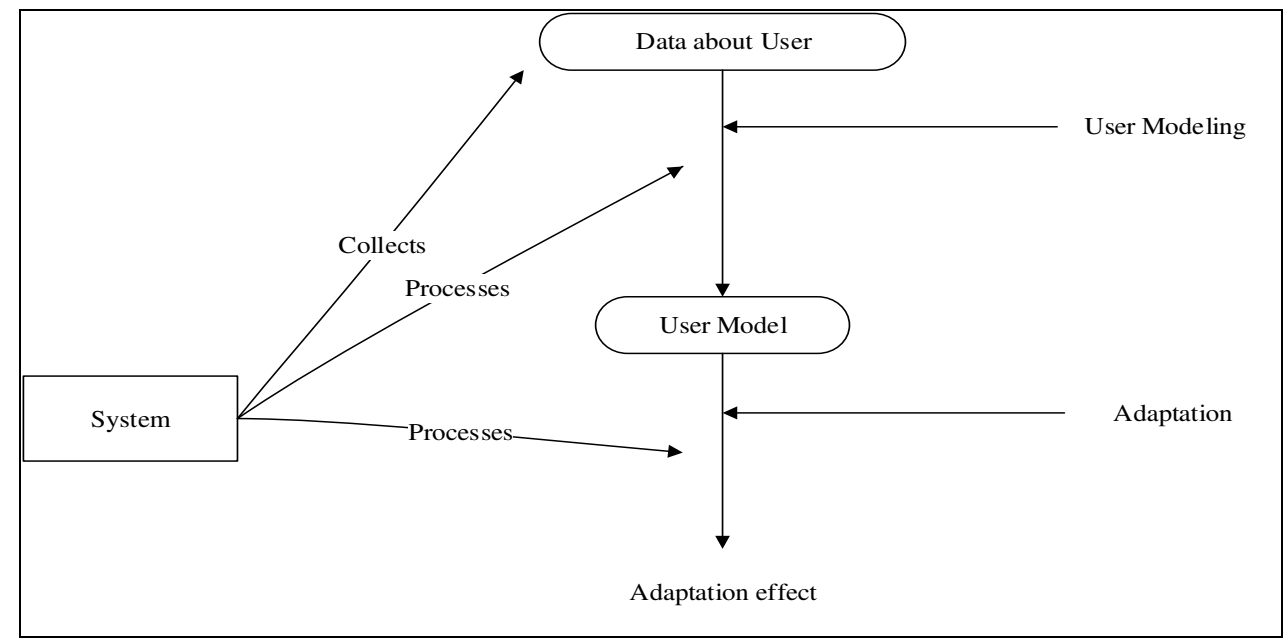

Gambar 1 Model System E-learning Adaptif.

Proses dari model sistem adaptif terdiri dari tiga tahap, yaitu:

1. Proses pengumpulan data tentang profil pengguna (user profile), merupakan proses untuk mendapatkan informasi awal tentang pengguna. Informasi yang didapatkan akan disimpan pada model pengguna (user model), yang dimulai dari tingkat pengetahuan awal, membangun pengetahuan, menambah pengetahuan dan pemeliharaan pengetahuan.

2. Proses membangun model pengguna (user model), dihasilkan dari proses pengumpulan informasi profil pengguna yang dikategorikan sebagai student's behavior, student's knowledge, student's achievement, student's preferences. Beberapa tujuan dari user model dalam sistem adaptif adalah memberikan informasi konten pembelajaran yang sesuai dengan student's behavior, menyesuaikan user interface dengan mahasiswa, membantu mahasiswa menemukan informasi yang dibutuhkan, memberikan umpan balik kepada mahasiswa tentang pengetahuannya dan memberikan bantuan dalam penggunaan sistem. Oleh karena itu sistem e-learning adaptif mempunyai kemampuan untuk mengubah informasi student's behavior pada user model.

3. Proses model adaptasi (adaptation model).

Model adaptasi berisi satu set aturan adaptasi yang dinyatakan dalam wujud ketentuan dan tindakan suatu kondisi tertentu pada sistem adaptif. Aturan adaptasi tersebut diproses oleh model adaptasi berdasarkan hasil informasi dari model user. Nodel adaptasi akan mengahasilkan sistem adaptif pada sistem e-learning adaptif[5].

B. Metode Numerik

Metode numerik berlaku secara umum, yaitu dapat diterapkan untuk persoalan matematika sederhana(yang dapat diselesaikan dengan metode analitik) maupun persoalan matematika rumit (yang metode analitik pun belum tentu dapat menyelesaikannya).

Perlunya belajar metode numerik memiliki beberapa alasan

1. Metode numerik merupakan alat bantu pemecahan masalah matematika yang sangat ampuh.

2. Kita bisa membuat sendiri program komputer tanpa membeli paket programnya.

3. Metode numerik menyediakan sarana untuk memperkuat kembali pemahaman matematika. Karena metode numerik ditemukan dengan menyederhanakan matematika yang lebih tinggi menjadi operasi matematika yang mendasar.

Peran computer didalam metode numerik antara lain untuk memprogram. langkah-langkah metode numerik diformulasikan menjadi program komputer. Program ditulis dengan bahasa pemrograman tertentu, seperti FORTRAN, PASCAL, C, BASIC, dan sebagainya. Kemajuan komputer digital telah membaut 
bidang metode numerik berkembang secara dramatis. Tidak ada bidang matematika lain yang mengalami kemajuan penting secepat metode numerik[6].

\section{Sistem Pendukung Keputusan / Decision Support Sistem (DSS)}

DSS merupakan sistem informasi interaktif yang menyediakan informasi, permodelan, dan pemanipulasian data. Sistem itu digunakan untuk membantu pengambilan keputusan dalam situasi semi terstruktur dan situasi yang tidak terstruktur, di mana tak seorang pun tahu secara pasti bagaimana keputusan seharusnya dibuat Alter [7].

DSS biasanya dibangun untuk mendukung solusi atas suatu masalah atau untuk mengevaluasi suatu peluang. DSS seperti itu disebut aplikasi DSS. Aplikasi DSS digunakan dalam pengambilan keputusan. Aplikasi DSS menggunakan CBIS (Computer Based Information System) yang fleksibel, interaktif, dan dapat diadaptasi, yang dikembangkan untuk mendukung solusi atas masalah manajemen spesifik yang tidak terstruktur.

\section{Simple Additive Weighting(SAW)}

Metode SAW sering juga dikenal istilah metode penjumlahan terbobot. Konsep dasar metode SAW adalah mencari penjumlahan terbobot dari rating kinerja pada setiap alternatif pada semua atribut Fishburn, MacCrimmon [8]. Metode SAW membutuhkan proses normalisasi matriks keputusan (X) ke suatu sekala yang dapat diperbandingkan dengan semua rating alternatif yang ada.

$$
r_{i j}= \begin{cases}\frac{x_{i j}}{\operatorname{Max}_{i j}} & \text { Jika jeuntungan adalah atribut } \\ \frac{\operatorname{Min}_{i} x_{i j}}{x_{i j}} & \text { Jika } j \text { adalah atribut biaya }\end{cases}
$$

Di mana $r_{-} i j$ adalah rating kinerja ternormalisai dari alternatif A_i pada atribut $C_{j} ; i=1,2, \ldots, m$ dan $j=1,2, \ldots, n$. Nilai preferensi untuk setiap alternatif $\left(\mathrm{V}_{\mathrm{C}} \mathrm{i}\right)$ diberikan sebagai:
$V_{i}=\sum_{j=1}^{n} w_{j} r_{i j}$

Nilai $V_{i}$ yang lebih besar mengindikasikan bahwa alternatif $A_{i}$ lebih terpilih.

Kasus:

Suatu perusahaan di Daerah Istimewa Yogyakarta (DIY) ingin membangun sebuah gudang yang akan digunakan sebagai tempat untuk menyimpan sementara hasil produksinya. Ada 3 lokasi yang akan menjadi alternatif, yaitu: $A_{1}=$ Ngemplak, $A_{2}=$ Kalasan, $A_{3}=$ Kota Gedhe . Ada 5 kriteria yang dijadikan acuan dalam pengambilan keputusan, yaitu:

1. $\mathrm{C} 1=$ jarak dengan pasar terdekat $(\mathrm{km})$,

2. $\mathrm{C} 2=$ kepadatan penduduk di sekitar lokasi (orang/km2);

3. $\mathrm{C} 3=$ jarak dari pabrik $(\mathrm{km})$;

4. $\mathrm{C} 4=$ jarak dengan gudang yang sudah ada $(\mathrm{km})$;

5. $\mathrm{C} 5=$ harga tanah untuk lokasi $(\times 1000$ $\mathrm{Rp} / \mathrm{m} 2)$.

Rating kecocokan setiap aternatif pada setiap kriteria, dinilai dengan 1 sampai 5 , yaitu:

1 = sangat rendah,

2 = rendah,

3 = cukup,

4 = tinggi,

$5=$ sangat tingi .

Tabel 1. Rating Kecocokan Dari Setiap Alternatif Pada Setiap Kriteria

\begin{tabular}{|l|c|c|c|c|c|}
\hline \multirow{2}{*}{ Alternatif } & \multicolumn{5}{|c|}{ Kriteria } \\
\cline { 2 - 6 } & $\mathrm{C}_{1}$ & $\mathrm{C}_{2}$ & $\mathrm{C}_{3}$ & $\mathrm{C}_{4}$ & $\mathrm{C}_{5}$ \\
\hline $\mathrm{A}_{1}$ & 4 & 4 & 5 & 3 & 3 \\
\hline $\mathrm{A}_{2}$ & 3 & 3 & 4 & 2 & 3 \\
\hline $\mathrm{A}_{3}$ & 5 & 4 & 2 & 2 & 2 \\
\hline
\end{tabular}

Karena setiap nilai yang diberikan pada setiap alternatif di setiap kriteria merupakan nilai kecocokan (nilai terbesar adalah yang terbaik), maka semua kriteria diberikan diasumsikan sebagai kriteria keuntungan. Pengambil keputusan memberikan bobot preferensi sebagai: $\mathrm{W}=(5,3,4,4,2)$

Matriks keputusan dibentuk dari tabel kecocokan sebagai berikut: 
$X=\left[\begin{array}{lllll}4 & 4 & 5 & 3 & 3 \\ 3 & 3 & 4 & 2 & 3 \\ 5 & 4 & 2 & 2 & 2\end{array}\right]$

Pertama-tama, dilakukan

normalisasi

matriks $X$ berdasarkan

persamaan

sebagai berikut:

$r_{11}=\frac{4}{\max \{4 ; 3 ; 5\}}=\frac{4}{5}=0,8$

$r_{21}=\frac{3}{\max \{4 ; 3 ; 5\}}=\frac{3}{5}=0,6$

$r_{31}=\frac{5}{\max \{4 ; 3 ; 5\}}=\frac{5}{5}=1$

$r_{21}=\frac{4}{\max \{4 ; 3 ; 4\}}=\frac{4}{4}=1$

$r_{22}=\frac{3}{\max \{4 ; 3 ; 4\}}=\frac{3}{4}=0,75$

$r_{32}=\frac{4}{\max \{4 ; 3 ; 4\}}=\frac{4}{4}=1$

Dan seterusnya, sehingga diperoleh matriks ternormalisasi $\mathrm{R}$ sebagai berikut:

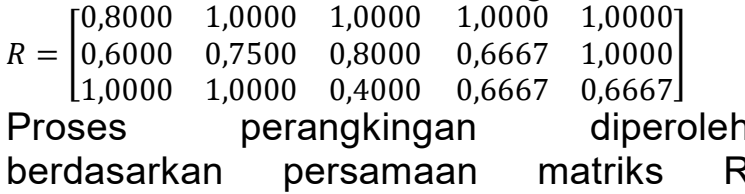
sebagai berikut:

$\mathrm{V} 1=(5)(0,8)+(3)(1)+(4)(1)+(4)(1)+(2)(1)=17$
$V 2=(5)(0,6)+(3)(0,75)+(4)(0,8)+(4)(0,6667)$ $+(2)(1)=13,1167$

$V 3=(5)(1)+(3)(1)+(4)(0,4)+(4)(0,6667)+(2)($ $0,6667)=13,6$

Nilai terbesar ada pada $\mathrm{V} 1$ sehingga alternative A1 adalah alternatif yang terpilih sebagai alternative terbaik. Dengan kata lain, Ngemplak akan terpilih untuk mendirikan gudang baru.

\section{METODOLOGI PENELITIAN}

A. Analisis Masalah dan Usulan Solusi

Aplikasi Pengembangan Sistem Adaptive Learning Menggunakan Metode SAW(Simple Additive Weighting) untuk Menentukan Nilai Pembelajaran pada Mata Kuliah Metode Numerik ini menggunakan metode Research and Development dengan model ADDIE. Model ADDIE merupakan singkatan dari Analysis, Design, Development, Implemnetation, and Evaluation. Model ini dipilih karena model ADDIE sering digunakan untuk menggambarkan pendekatan sistematis untuk pengembangan instruksional[9]. Pada Gambar 2 adalah menggambarkan tahapan dalam metode ADDIE.

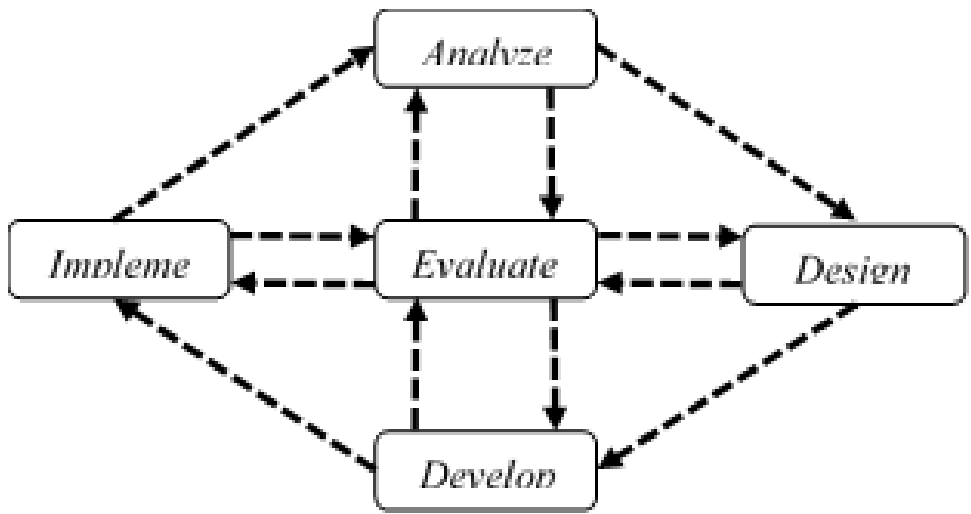

Gambar 2. Ilustrasi Model ADDIE

Dari data-data yang terkumpul dapat ditentukan system yang akan dibangun yaitu Sistem Adaptive Learning Menggunakan Metode SAW(Simple Additive Weighting) untuk Menentukan Nilai Pembelajaran pada Mata Kuliah Metode Numerik. Di dalam pengembangan perangkat lunak ini nantinya akan mengadopsikan metode adaptif, di mana sistem yang dibangun dapat melakukan proses adaptasi terhadap penggunanya. Adaptasi yang dilakukan oleh sistem adalah tingkat pengusaan materi Metode Numerik dari pengguna. Materi yang dimuat bersifat terstruktur jadi materi harus bisa dikuasai untuk bisa melanjutkan ke materi berikutnya. Tingkat penguasaan materi akan diukur menggunakan evaluasi berupa test objektif dengan nilai standar 
yang akan ditentukan oleh Dosen. Apabila nilai tidak memenuhi standar, sistem akan mengarahkan pengguna untuk mempelajari materi secara berulang yang berkaitan dengan test evaluasi.

Menghitung hasil evaluasi proses pembelajaran dari mahasiswa akan digunakan metode SAW(Simple Additive Weighiting). Untuk penentuan kreteria didalam metode session test adalah nilai dan banyak session. Kriteria tersebut diperoleh dari kajian teori yang telah dipaparkan dan angket wawancara dari pengampu mata kuliah Metode Numerik Pendidikan Teknik Informatika, Fakultas Teknik dan Kejuruan, UNDIKSHA. Berikut ini merupakan contoh data yang digunakan dalam perhitungan metode SAW (Simple Additive Weighting).

Tabel 2. Data Mahasiswa

\begin{tabular}{|l|l|c|c|}
\hline No & Nama Mahasiswa & Nilai & Session \\
\hline 1. & I Putu Suastika Putra & 80 & 2 \\
\hline 2. & I Komang Subagy Adi Putra & 78 & 1 \\
\hline 3. & Ida Ayu Nindhya Patanjali & 98 & 1 \\
\hline 4. & I Putu Budiarsana & 84 & 3 \\
\hline 5. & Ni Luh Kadek Ari & 79 & 2 \\
\hline 6. & Ni Luh Putu Sri Wahyuni & 99 & 3 \\
\hline 7. & I Putu Putra Adnyana & 97 & 1 \\
\hline 8. & I Gede Arta Wiguna & 76 & 2 \\
\hline 9. & I Wayan Siki Arta & 75 & 3 \\
\hline 10. & I Kadek Darmayasa & 88 & 2 \\
\hline
\end{tabular}

1. Perumusan Masalah Menentukan nilai akhir mahasiswa.

2. Penentuan Alternatif Pada Tabel 2 ada 10 mahasiswa yang akan ditentukan alternatif nilai akhirnya.

Tabel 3. Alternatif Nilai Mahasiswa

\begin{tabular}{|c|l|}
\hline Kode & \multicolumn{1}{|c|}{ Mahasiswa } \\
\hline A1 & I Putu Suastika Putra \\
\hline A2 & I Komang Subagy Adi Putra \\
\hline A3 & Ida Ayu Nindhya Patanjali \\
\hline A4 & I Putu Budiarsana \\
\hline A5 & Ni Luh Kadek Ari \\
\hline A6 & Ni Luh Putu Sri Wahyuni \\
\hline A7 & I Putu Putra Adnyana \\
\hline A8 & I Gede Arta Wiguna \\
\hline A9 & I Wayan Siki Arta \\
\hline A10 & I Kadek Darmayasa \\
\hline
\end{tabular}

3. Penentuan Kriteria

Kriteria yang digunakan pada setiap Materi untuk pemberian nilai akhir diuraikan pada Tabel 4.

Tabel 4. Kriteria Nilai Akhir

\begin{tabular}{|c|l|}
\hline Kode & Hasil Akhir \\
\hline C1 & Nilai \\
\hline
\end{tabular}

4. Menentukan Bobot Preferensi

Di dalam pemberian bobot nantinya akan diinputkan sesuai keiingin dosen pengampu mata kuliah yang bersangkutan

Tabel 5. Nilai Bobot Preferensi

\begin{tabular}{|c|c|c|}
\hline Kriteria & Nilai & Session \\
\hline Bobot & 10 & 1 \\
\hline
\end{tabular}

5. Melakukan identifikasi jenis kriteria apakah termasuk kriteria keuntungan (benefit) atau kriteria biaya (cost).

Tabel 6. Identifikasi Jenis Kreteria Nilai Akhir

\begin{tabular}{|c|l|l|}
\hline No & \multicolumn{1}{|c|}{ Kriteria } & \multicolumn{1}{c|}{ Jenis Kriteria } \\
\hline 1. & Nilai & Max \\
\hline 2. & Session & Min \\
\hline
\end{tabular}

6. Memberikan nilai rating kecocokan setiap alternatif pada setiap kriteria.

Tabel 7. Nilai Rating Kecocokan

\begin{tabular}{|c|c|c|}
\hline Alt & Nilai & Session \\
\hline A1 & 80 & 2 \\
\hline A2 & 78 & 1 \\
\hline
\end{tabular}




\begin{tabular}{|c|c|c|}
\hline A3 & 98 & 1 \\
\hline A4 & 84 & 3 \\
\hline A5 & 79 & 2 \\
\hline A6 & 99 & 3 \\
\hline A7 & 97 & 1 \\
\hline A8 & 76 & 2 \\
\hline A9 & 75 & 3 \\
\hline A10 & 88 & 2 \\
\hline
\end{tabular}

7. Membuat matriks $(X)$ yang dibentuk dari tabel rating kecocokan dari setiap alternatif pada setiap kriteria.

Tabel 8. Matriks Keputusan

Berdasarkan Nilai Rating Kecocokan

\begin{tabular}{|c|c|c|}
\hline \multirow{2}{*}{ Alt } & \multicolumn{2}{|c|}{ Kriteria (C) } \\
\cline { 2 - 3 } & Nilai & Session \\
\cline { 2 - 3 } & Max & Min \\
\hline A1 & 80 & 2 \\
\hline A2 & 78 & 1 \\
\hline A3 & 98 & 1 \\
\hline A4 & 84 & 3 \\
\hline A5 & 79 & 2 \\
\hline A6 & 99 & 3 \\
\hline A7 & 97 & 1 \\
\hline A8 & 76 & 2 \\
\hline A9 & 75 & 3 \\
\hline A10 & 88 & 2 \\
\hline
\end{tabular}

8. Membuat matriks (X) yang dibentuk dari tabel rating kecocokan dari setiap alternatif pada setiap kriteria.

$X=\left[\begin{array}{ll}80 & 2 \\ 78 & 1 \\ 98 & 1 \\ 84 & 3 \\ 79 & 2 \\ 99 & 3 \\ 97 & 1 \\ 76 & 2 \\ 75 & 3 \\ 88 & 2\end{array}\right]$

9. Melakukan normalisasi matriks keputusan dengan cara menghitung rating kinerja ternormalisasi (rij) dari alternatif Ai pada kinerja $\mathrm{Cj}$.
10. Hasil dari nilai rating kinerja ternormalisasi (rij) membentuk matriks ternormalisasi $(\mathrm{R})$.

$$
R=\left[\begin{array}{ll}
0,800 & 0,500 \\
0,780 & 1,000 \\
0,980 & 1,000 \\
0,840 & 0,333 \\
0,790 & 0,500 \\
0,990 & 0,333 \\
0,970 & 1,000 \\
0,760 & 0,500 \\
0,750 & 0,333 \\
0,880 & 0,500
\end{array}\right]
$$

11. Hasil akhir dari nilai preferensi (Vi) diperoleh dari penjumlahan dari perkalian elemen baris matriks ternormalisai (R) dengan bobot preferensi (W) yang bersesuaian elemen kolom matriks $(\mathrm{W})$.
1) $\mathrm{V} 1=(0,800)(10)+(0,500)(1)=8,50$
2) $\mathrm{V} 2=(0,780)(10)+(1,000)(1)=8,80$
3) $\mathrm{V} 3=(0,980)(10)+(1,000)(1)=10,80$
4) $\mathrm{V} 4=(0,840)(10)+(0,333)(1)=8,73$
5) $\mathrm{V} 5=(0,790)(10)+(0,500)(1)=8,40$
6) $\mathrm{V} 6=(0,990)(10)+(0,333)(1)=10,23$
7) $\mathrm{V} 7=(0,970)(10)+(1,000)(1)=10,70$
8) $\mathrm{V} 8=(0,760)(10)+(0,500)(1)=8,10$
9) $\mathrm{V} 9=(0,750)(10)+(0,333)(1)=7,83$
10) $\mathrm{V} 10=(0,880)(10)+(0,500)(1)=9,30$

12. Dari hasil akhir nilai preferensi (Vi) dilakukan normalisasi nilai dengan cara nilai (Vi) dikalikan dengan nilai 100 dan di bagi dengan jumlah (W) dari $\mathrm{Cj}$ makan di dapatkan hasil (Vi) yang baru.
1) $\mathrm{V} 1=(8,50 * 100) / 11=77,272$
2) $\mathrm{V} 2=(8,80 * 100) / 11=80,000$
3) $\mathrm{V} 3=(10,80 * 100) / 11=98,181$
4) $\mathrm{V} 4=\left(8,73^{*} 100\right) / 11=79,363$
5) $\mathrm{V} 5=(8,40 * 100) / 11=76,363$
6) $\mathrm{V} 6=(10,23 * 100) / 11=93,000$
7) $\mathrm{V} 7=(10,70 * 100) / 11=97,272$
8) $\mathrm{V} 8=(8,10 * 100) / 11=73,636$
9) $\mathrm{V} 9=(7,83 * 100) / 11=71,181$
10) $\mathrm{V} 10=(9,30 * 100) / 11=84,545$

13. Dari perhitungan nilai Vi tersebut maka didapatkan nilai akhir mahasiswa.

Tabel 9. Nilai Akhir

\begin{tabular}{|l|l|c|}
\hline No. & \multicolumn{1}{|c|}{ Nama Mahasiswa } & Nilai Akhir \\
\hline 1. & Ida Ayu Nindhya Patanjali & 98 \\
\hline 2. & I Putu Putra Adnyana & 97 \\
\hline
\end{tabular}




\begin{tabular}{|l|l|l|}
\hline 3. & Ni Luh Putu Sri Wahyuni & 93 \\
\hline 4. & I Kadek Darmayasa & 85 \\
\hline 5. & I Komang Subagy Adi Putr & 80 \\
\hline 6. & I Putu Budiarsana & 79 \\
\hline 7. & I Putu Suastika Putra & 77 \\
\hline 8. & Ni Luh Kadek Ari & 76 \\
\hline 9. & I Gede Arta Wiguna & 74 \\
\hline 10. & I Wayan Siki Arta & 71 \\
\hline
\end{tabular}

B. Model Fungsional Sistem

$$
\text { Secara umum alur dari }
$$

Pengembangan Sistem Adaptive Learning Menggunakan Metode SAW(Simple
Additive Weighting) untuk Menentukan Nilai Pembelajaran Pada Mata Kuliah Metode Numerik digambarkan dengan diagram alir pada gambar 3 .

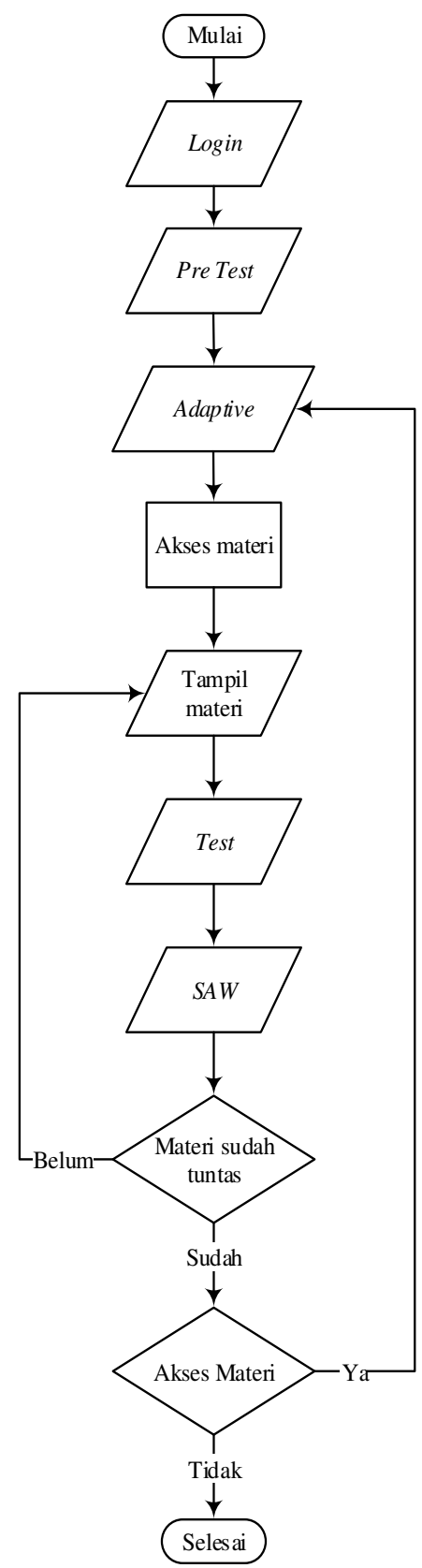

Gambar 3 Alur Pembuatan Perangkat Lunak 
Untuk rancangan antar table pada system ini menggambarkan hubungan antar tabletabel dalam basisdata dari Pengembangan Sistem Adaptive Learning Menggunakan Metode SAW(Simple Additive Weighting) untuk Menentukan Nilai Pembelajaran Pada Mata Kuliah
Metode Numerik. Pada tahap perancangan, terdapat 11 tabelyang mendukung didalam pembuatan system. Berikut ini adalah gambar dari relasi antar table perancangan system.
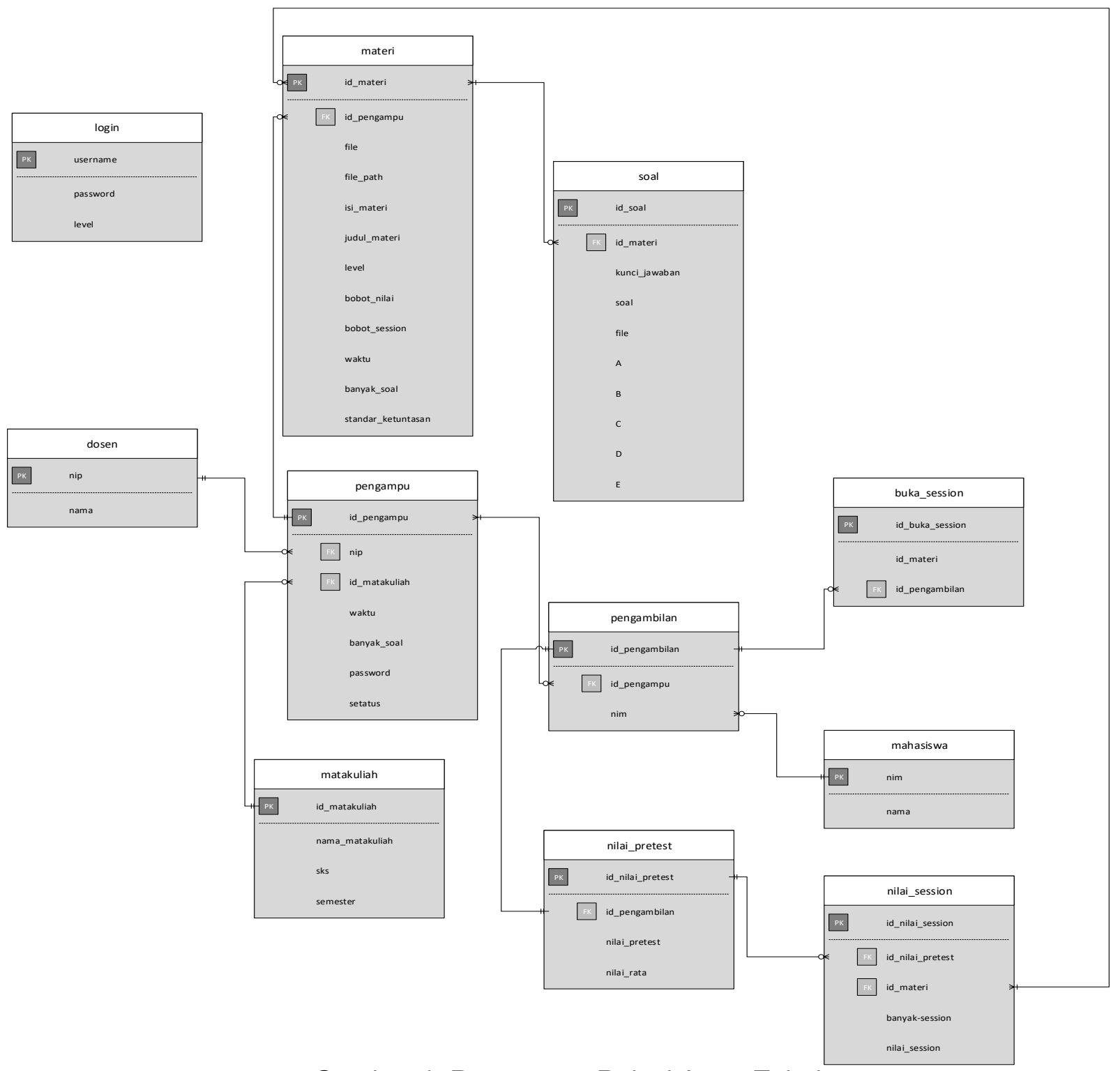

Gambar 4. Rancangan Relasi Antar Tabel

\section{IMPLEMENTASI DAN PENGUJIAN}

A. Implementasi Perangkat Lunak

1. Arsitektur Perangkat Lunak

Arsitektur perangkat lunak ini menggunakan model client-server yang dapat digunakan dengan bantuan internet. 


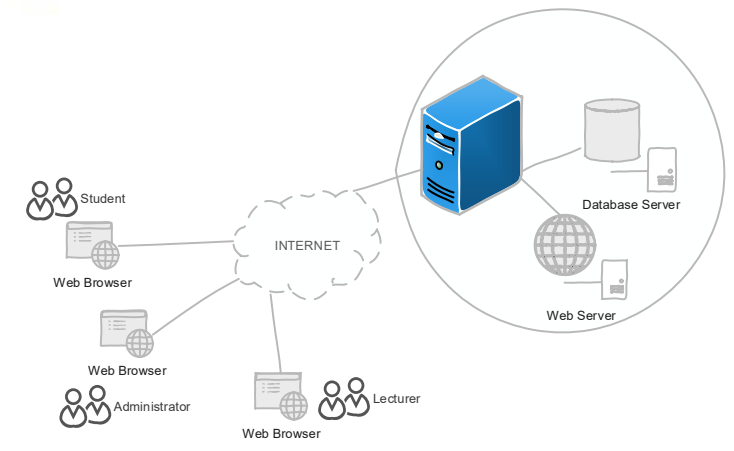

Gambar 5. Arsitektur Perangkat Lunak

Pada Gambar 5 digambarkan arsitektur sistem yang terdiri dari tiga jenis pengguna yaitu Mahasiswa, Dosen pengampu matakuliah, dan administrator.
Yang masing-masing pengguna memiliki hak akses yang berbeda-beda. Seperti mahasiswa tidak bisa mengakses halaman administrator, dosen pengampu mata kuliah juga tidak dapat mengakses halaman administrator.

2. Implementasi Tampilan Antar Muka

a. Implementasi Halaman Login

Halaman login adalah halaman pertama yang ditampilkan system sebelum masuk kedalam system berdasarkan hak aksesnya. Pada Gambar 6 adalah tampilan login pada system.

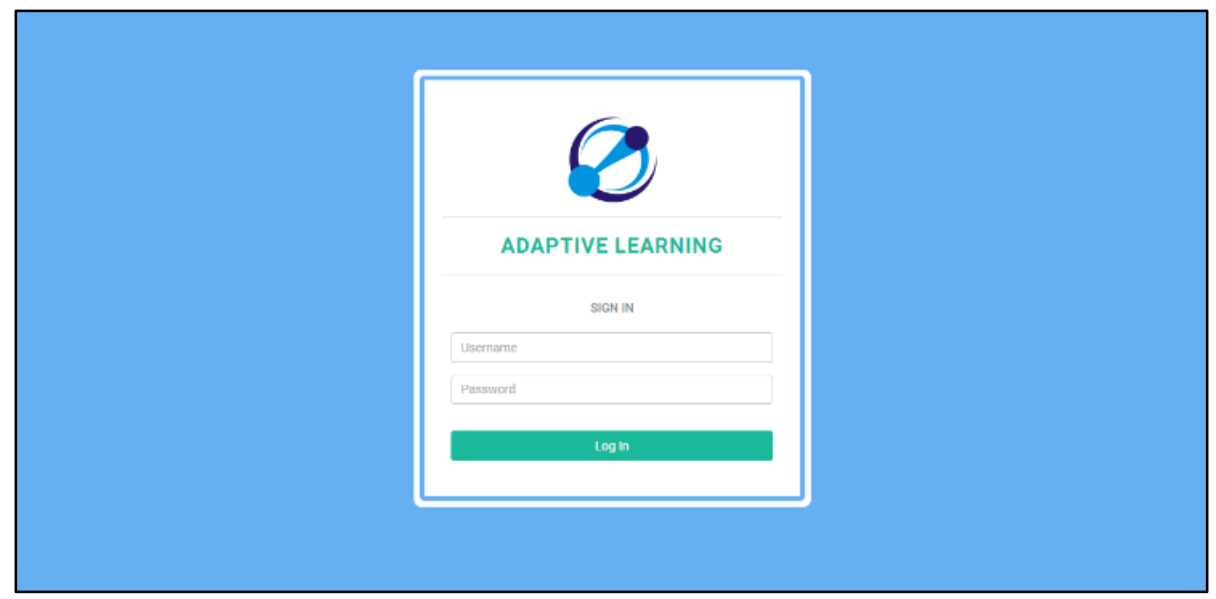

Gambar 6. Tampilan Login

b. Implementasi Halaman Pre Test

Halaman pre test merupakan halaman pertama pada mahasiswa ketika masuk didalam proses pembelajaran system untuk mengetahui kemampuan awal mahasiswa terhadap materi yang akan dipelajari. . Pada Gambar 7 adalah tampilan pre test pada system.

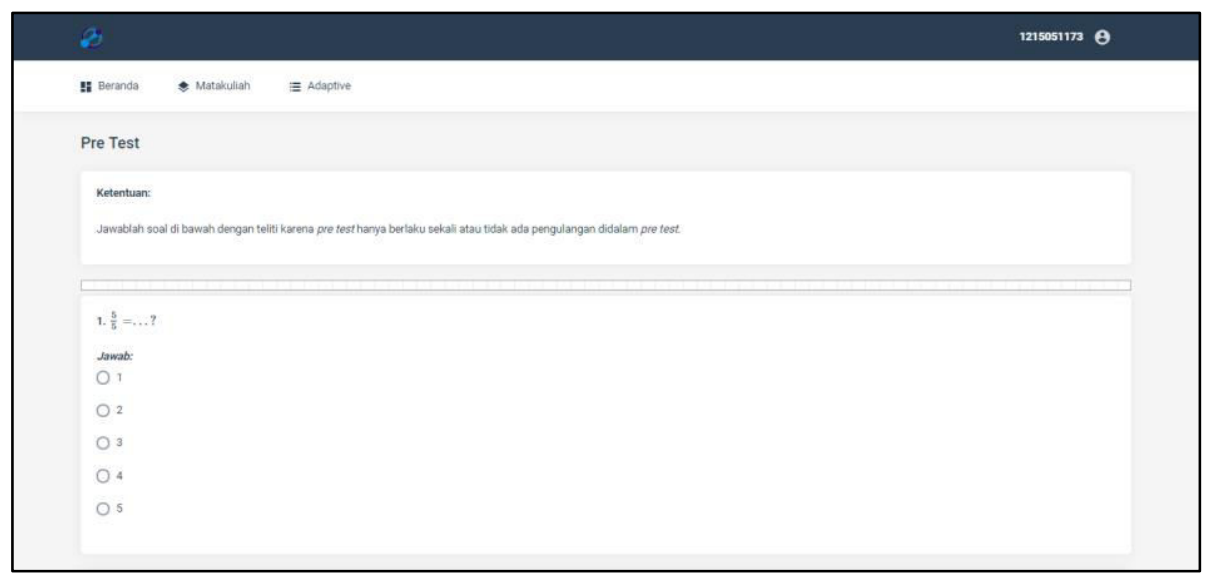

Gambar 7. Tampilan Pre Test 
c. Implementasi Halaman Session Test

Halaman session test merupakan halaman berupa test dengan soal pilihan untuk mengevaluasi pengetahuan mahasiswa terhadap materi yang sudah dipelajari. Proses evalusi disini mengadopsi metode SAW. . Pada Gambar 8 adalah tampilan session test pada system

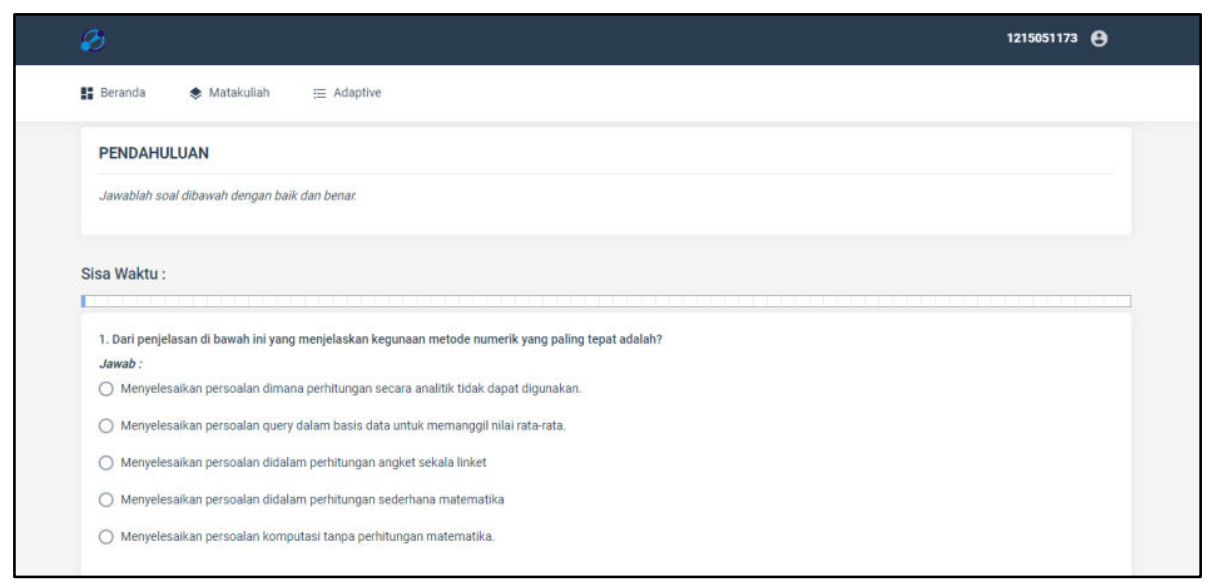

Gambar 8. Tampilan Session Test

B. Hasil Pengujian Perangkat Lunak

Secara menyeluruh hasil dari semua pengujian yang telah dilakukan, dapat dilaksanakan dengan baik sesuai dengan tujuan dari pengujian baik dalam pengujian kotak putih, pengujian kotak hitam, pengujian kesesuaian sistem, pengujian ahli media pada sistem, serta pengujian respons pengguna terhadap sistem.

Pengujian kotak putih (white box) yang bertujuan menguji alur proses dan logika yang ada sudah dapat terlaksana dengan baik dan benar. Sehingga dapat dikatakan bahwa semua alur proses dan logika yang diimplementasikan ke sistem sudah berjalan dengan baik dan benar. Kemudian berdasarkan pengujian kotak hitam (black box) yang bertujuan menguji fungsional sistem yang dibuat juga sudah dapat terlaksana dengan baik dan sesuai dengan masukkan dan keluaran yang diberikan sistem.

Untuk uji kesesuaian sistem juga sudah dapat diimplementasikan dengan baik. Pengujian ini menunjukkan bahwa tidak ada perbedaan yang signifikan antara perhitungan manual dan sistem berdasarkan metode yang digunakan. Uji respon pengguna didapatkan hasil $81,87 \%$ menyatakan bahwa system sudah dapat berjalan dengan baik sesuai dengan harapan pengguna.

\section{SIMPULAN}

Berdasarkan penelitian pada Pengembangan Sistem Adaptive Learning Menggunakan Metode SAW(Simple Additive Weighting) Untuk Menentukan Nilai Pembelajaran Pada Matakuliah Metode Numerik dapat disimpulkan sebagai berikut.

Pengembangan Sistem Adaptive Learning Menggunakan Metode SAW(Simple Additive Weighting) untuk Menentukan Nilai Pembelajaran pada Matakuliah Metode Numerik dirancang menggunakan flowchart dan diimplementasikan dengan menggunakan bahasa pemrograman PHP dan Javascript dengan menggunakan salah satu framework PHP yaitu $\mathrm{Cl}$ (Codeigniter).

Hasil uji kesesuaian dari Pengembangan Adaptive Learning Menggunakan Metode SAW (Simple Additive Weighting) untuk Menentukan Nilai Pembelajaran pada Mata Kuliah Metode Numerik menyatakan bahwa antara perhitungan manual dan sistem 
sudah sangat sesuai berdasarkan pada metode perhitungan yang digunakan.

Respon mahasiswa

Jurusan

Pendidikan Teknik Informatika Fakultas

Teknik dan Kejuruan Universitas

Pendidikan Ganesha terhadap

penggunaan Sistem Adaptive Learning Menggunakan Metode SAW(Simple Sdditive Weighring) untuk Menentukan Nilai Pembelajaran pada Mata Kuliah Metode Numerik menyatakan bahwa system sudah berjalan dengan baik dengan total persentase $81,87 \%$ dari hasil perhitungan angket respon mahasiswa.

Berdasarkan dari kesimpulan tersebut disarankan kepada pembaca untuk pengembangan selanjutnya dapat mengembangkan Sistem Adaptive Learning Menggunakan Metode SAW(Simple Additive Weighting) untuk Menentukan Nilai Pembelajaran pada Matakuliah Metode Numerik dengan menambahkan atau mengganti metode apabila menemukan metode lain yang dirasa cocok untuk menentukan hasil belajar pada matakuliah Metode Numerik.

\section{REFERENSI}

[1] Sardiman A.M. (2010). Interaksi \& Motivasi Belajar Mengajar. Jakarta: Rajawali Pers.

[2] Wirawan, I. A., \& Gitakarna, M. S. (2015). Development of Adaptive Mobile Learning (AML) on. (IJCSA) International Journal of Advanced Computer Science and Application, 197-202.

[3] E.S, H. Susana, \& Sriyansyah. (2015). Analisis Didaktis Berdasarkan Kemampuan Kognetif dan Ketrampilan Berpikir Siswa pada Materi Kalor. JPPPF - Jurnal Penelitian \& Pengembangan Pendidikan Fisika, 39-44.

[4] Sumanti, \& Tutin. (2013). Sistem Pendukung Keputusan Pemilihan Mobil Bekas Dengan Menggunakan Metode Simple Additive Weighting(SAW). Pelita Informatika Budi Darma, 139-142.

[5] Hernawati, K. (2011). E-Learning Adaptive Berbasis Karakteristik
Peserta Didik. Prosiding Seminar Nasional Penelitian, 63-74.

[6] Ir. Rinaldi Munir, M. (2002). Metode Numerik Untuk Teknik Informatika Edisi Kedua(Revisi). Bandung: Departemen Teknik Informatika.

[7] Kusrini M.Kom. (2007). Konsep dan Aplikasi Sistem Pendukung Keputusan. Yogyakarta: C.V ANDI OFFSET.

[8] Kusumadewi, S., Hartati, S., Harjoko, A., \& Retantyo, W. (2010). Fuzzy Multi-Attribute Decision Making (FUZZY MADM). Yogyakarta: GRAHA ILMU.

[9] Sugihartini, N., \& Jayanta, N. L. (2017). Pengembangan E-Modul Mata Kuliah Strategi Pembelajaran. Jurnal Pendidikan Teknologi dan Kejuruan, 221-230.

[10] Haviludin. (2011). Memahami Penggunaan UML(Unified Modeling Language). Jurnal Informatika Mulawarman, 1-15.

[11] Ilhamsyah . (2014). Sistem Pendukung Keputusan untuk Menyeleksi Calon Siswa Sekolah Menengah Kejuruan (SMK) Dwi Tunggal Tanjung Morawa Menggunakan Model Multi-Atribute Decission Making (MADM) Dengan Metode Simple Additive Weighting (SAW). Pelita Informatika Budi Darma, 140-145.

[12] Roestiyah N.K. (2008). Strategi Belajar Mengajar. Jakarta: Rineka Cipta. Rosa, A. S., \& Sahaluddin, M. (2013). Rekayasa Perangkat Lunak. Bandung: Informatika.

[13] Rosa, A. S., \& Sahaluddin, M. (2013). Rekayasa Perangkat Lunak. Bandung: Informatika.

[14] Suarni, N. K., \& Dantes, G. R. (2012). Implementasi Dynamic Intelectual Learning (DIL) Sebagai Salah Satu Adaptive Learning Model. Jurnal Sains dan Teknologi, 19-34.

[15] Tegeh, I. M., \& Kirna, I. M. (2010). Metode Penelitian Pengembangan. Singaraja : Universitas Pendidikan Ganesha. 
[16] Tegeh, I., \& Kirna , I. (2013).

Pengembangan Bahan Ajar Metode

Penelitian Pendidikan dengan ADDIE
Model. Pengembangan Bahan Ajar, 12-26. 